\title{
Comparative Performance of Chemical and Biological-based Products in Management of Algal Leaf Spot on Magnolia
}

\author{
Fulya Baysal-Gurel $^{1}$, Ravi Bika ${ }^{1}$, Christina Jennings ${ }^{1}$, \\ Cristi Palmer ${ }^{2}$, and Terri Simmons ${ }^{1}$
}

ADDITIONAL INDEX WORDs. biorational products, Cephaleuros virescens, fungicides, 'Jane' magnolia, Magnolia grandiflora, nursery production, southern magnolia

SumMARy. Magnolia trees (Magnolia sp.) are a popular choice for consumers when choosing flowering woody plants for landscapes. Magnolia species grow in a wide variety of both temperate and tropical locations. Southern magnolia (Magnolia grandiflora) is one of the more popular magnolias due to its pleasing aesthetics: large showy flowers in a range of colors and evergreen foliage. However, magnolias can be affected by algal leaf spot. Algal leaf spot is caused by Cephaleuros virescens, which is a widespread plant parasitic green alga. There has been little research on how to treat algal leaf spot on magnolia plants. This study focuses on identifying effective biological- and chemical-based fungicides for the management of algal leaf spot disease of magnolia plants. Two experiments were conducted in a randomized complete block design with six replications per treatment and a total of 12 treatments, including a nontreated control. The first experiment (Expt. 1) was conducted in a shade house ( $56 \%$ shade) at McMinnville, TN, using southern magnolia plants. The second experiment (Expt. 2) was conducted at a commercial nursery in McMinnvillle, TN, in a field plot planted with 'Jane' magnolia (Magnolia liliiflora 'Nigra' $\times$ Magnolia stellata 'Rosea'). The algal leaf spot disease severity, disease progression, plant marketability and growth parameters were evaluated. In both experiments, all treatments reduced algal leaf spot disease severity and disease progress in comparison with the nontreated control. In Expt. 1, copper octanoate, copper oxychloride, chlorothalonil water-dispersible granules, chlorothalonil suspension concentrate, didecyl dimethyl ammonium chloride, azoxystrobin + benzovindiflupyr, hydrogen peroxide + peroxyacetic acid, and mono- and dipotassium salts of phosphorus acid + hydrogen peroxide reduced the disease severity and disease progress the most and were not statistically different from one another. In Expt. 2, azoxystrobin + benzovindiflupyr, didecyl dimethyl ammonium chloride, and copper oxychloride significantly reduced disease severity and disease progress (area under disease progress curve). Treatments had no deleterious effect on plant growth parameters such as height and width, and no phytotoxicity of applied treatments or defoliation was observed. Treated magnolia plants had better plant marketability compared with the nontreated control plants. The findings of this study will help growers to achieve better management of algal leaf spot disease on magnolia trees.

$\mathrm{M}$ agnolias (Magnolia sp.) are in the family Magnoliaceae, and belong to a genus that consists of $\approx 240$ different species of large shrubs and trees native to Central America, South America, eastern North America, the Caribbean, and Southeast Asia (Knox et al., 2012). These areas range from tropical to temperate climates. When cultivated, magnolias tend to do best in moist, well-drained soils with full sun to light shade (Knox et al., 2012). Magnolias have been used for medicinal purposes and timber but are most commonly sought after for their landscape aesthetics contributed by both flowers and foliage (Knox et al., 2012).
Southern magnolia (Magnolia grandiflora) is a popular species due to its beautiful flowers, foliage, and plant form. In addition, southern magnolia is adaptable to a myriad of different conditions. This has led to a preference for southern magnolia in the landscape by consumers and landscape architects, and it is the most widely cultivated species of magnolia (Knox et al., 2012). However, southern magnolia, and other magnolias such as 'Jane' magnolia (Magnolia liliiflora 'Nigra' $\times$ Magnolia stellata 'Rosea'), are susceptible to several different pests and diseases, such as algal leaf spot caused by Cephaleuros virescens.

Cephaleuros is a genus of parasitic green algae that thrives in warm, moist conditions (Nelson, 2008; Pitaloka et al., 2015). Cephaleuros consists mostly of parasitic or endophytic species. C. virescens (previously known as Mycoidea parasitica) is a subcuticular species, and is the most regularly reported algal pathogen in this genus (Nelson, 2008; Zhu et al., 2017).

Cephaleuros virescens causes mostly leaf spots but also causes fruit spots, green scurf, and red rust in guava (Psidium guajava), tea (Camellia sinensis), and coffee (Coffea arabica) (Nelson, 2008; Old et al., 2000; Sunpapao et al., 2016; Suto and Ohtani, 2009). Algal leaf spot is found commonly between latitudes $32^{\circ} \mathrm{N}$ and $32^{\circ} \mathrm{S}$ in humid, tropical, and temperate regions, and it has been reported worldwide on a wide variety of hosts (Old et al., 2000; Rindi and Lopez-Bautista, 2008). In the United States, it was first observed in Florida (Swingle, 1894), and reported in many plant species including citrus (Citrus sp.) (Ruehle, 1936; Steven and Piper, 1941; Suit, 1949; Suit and DuCharme, 1946). Algal leaf spot is present from the Gulf coast of the southern United States to as far north along the Atlantic coast as North Carolina (Holcomb, 1986; Wellman, 1972). The pathogen is dispersed by wind or splashing water,

\begin{tabular}{llll}
\hline $\begin{array}{l}\text { Units } \\
\begin{array}{l}\text { To convert U.S. to SI, } \\
\text { multiply by }\end{array}\end{array}$ & U.S. unit & Sl unit & $\begin{array}{l}\text { To convert SI to U.S., } \\
\text { multiply by }\end{array}$ \\
\hline 29.5735 & $\mathrm{fl} \mathrm{oz}$ & $\mathrm{mL}$ & 0.0338 \\
7.8125 & $\mathrm{fl} \mathrm{oz} / \mathrm{gal}$ & $\mathrm{mL} \cdot \mathrm{L}^{-1}$ & 0.1280 \\
0.3048 & $\mathrm{ft}$ & $\mathrm{m}$ & 3.2808 \\
3.7854 & $\mathrm{gal}$ & $\mathrm{L}$ & 0.2642 \\
2.54 & $\mathrm{inch}(\mathrm{es})$ & $\mathrm{cm}$ & 0.3937 \\
0.5933 & $\mathrm{lb} / \mathrm{yard}{ }^{3}$ & $\mathrm{~kg} \cdot \mathrm{m}^{-3}$ & 1.6856 \\
28.3495 & $\mathrm{Oz}$ & $\mathrm{g}$ & 0.0353 \\
7.4892 & $\mathrm{oz} / \mathrm{gal}^{-3}$ & $\mathrm{~g} \cdot \mathrm{L}^{-1}$ & 0.1335 \\
6.8948 & $\mathrm{psi}$ & $\mathrm{kPa}$ & 0.1450 \\
$\left({ }^{\circ} \mathrm{F}-32\right) \div 1.8$ & ${ }^{\circ} \mathrm{F}$ & ${ }^{\circ} \mathrm{C}$ & $\left({ }^{\circ} \mathrm{C} \times 1.8\right)+32$ \\
& & &
\end{tabular}

Hortlechnology · December $202030(6)$ 
which causes hosts to be inoculated as sporangia are deposited on susceptible tissue.

The most common form of parasitism by $C$. virescens is leaf spot infection. The leaf spot infection starts as a yellow-green pinpoint that usually appears on the topside of the leaf (Fig. 1), but sometimes on the underside of the leaf as an irregular orange to red-brown disc. Leaf spots, as they enlarge up to $2 \mathrm{~cm}$ diameter, will often be raised and have a velvety appearance (Nelson, 2008). Leaf spot affects the lamina, veins, and petioles (Joubert and Rijkenberg, 1971). Infections are considered minor cosmetic issues because algae are subcuticular (Holcomb, 1986); however, subcuticular foliar infections may serve as a source of inoculum for more destructive stem infections (Joubert and Rijkenberg, 1971). Stem infections result in swelling, tissue damage, and bark splitting, ultimately causing twig death (Holcomb, 1986; Joubert and Rijkenberg, 1971; Wolf, 1830). In addition, defoliation of mango ( $\mathrm{Mag}$ nifera indica) and coffee trees, due to leaf spot infection, was observed under high disease pressure (Wellman, 1972).

In ornamental production, where the value of plants depends on the aesthetic beauty and ornamental characteristics, slight incidence of algal leaf spot disease can decrease the marketability. When disease pressure is high, copper fungicides are the only recommended products to manage this

Received for publication 14 July 2020. Accepted for publication 24 Sept. 2020.

Published online 26 October 2020

${ }^{1}$ Tennessee State University, Otis L. Floyd Research Center, Department of Agriculture and Environmental Sciences, McMinnville, TN 37110

${ }^{2}$ Rutgers University, IR-4, 500 College Road East, Suite 201, Princeton, NJ 08540

This project was funded by the IR-4 Project (U.S. Department of Agriculture-National Institute of Food and Agriculture award number 2017-34383-27100). We thank Albaugh, BioSafe Systems, BioWorks, Certis USA, Pace 49, SePRO Corporation, and Syngenta for donating the conventional fungicides and biorational products used in this study.

Mention of trade names of commercial products in the publication is solely for the purpose of providing specific information and does not imply recommendation or endorsement by Tennessee State University or IR-4.

F.B.-G. is the corresponding author. E-mail: fbaysalg@ tnstate.edu.

This is an open access article distributed under the CC BY-NC-ND license (https://creativecommons.org/ licenses/by-nc-nd/4.0/).

https://doi.org/10.21273/HORTTECH04692-20 disease. Therefore, there is clear need to determine whether additional tools can effectively manage algal leaf spot disease in nursery production.

At the IR-4 Environmental Horticulture Program Workshop in 2015 , an algal leaf spot efficacy study was selected as a regional special project for the southern United States (Palmer, 2015). The objective of this project was to evaluate different biological- and chemical-based fungicides for the management of algal leaf spot disease on magnolia. Those fungicides were also assessed for side effects such as phytotoxicity and growth impacts. The results of this study will provide nursery producers with potential treatments for algal leaf spot management.

\section{Materials and methods}

Two experiments were conducted in 2017. The first experiment (Expt. 1) was conducted in a shade house $(56 \%$ shade) at the Tennessee State University Otis L. Floyd Nursery Research Center in McMinnville, TN, using southern magnolia plants grown in 1 -gal pots. Growing media consisted of $100 \%$ pine (Pinus sp.) bark amended with $11.12 \mathrm{lb} /$ yard $^{3}$ $19 \mathrm{~N}-2.1 \mathrm{P}-7.4 \mathrm{~K}$ controlled-release fertilizer (Osmocote Pro; ICL Specialty Fertilizers, Dublin, $\mathrm{OH}), 1.01$ $\mathrm{lb} /$ yard $^{3}$ micronutrient fertilizer (Micromax; ICL Specialty Fertilizers), $1.01 \mathrm{lb} /$ yard $^{3}$ chelated iron (Fe) [Sprint $330(10 \% \mathrm{Fe})$; BASF, Florham, NJ], and $0.34 \mathrm{lb} /$ yard $^{3}$ Epsom salts containing 9.8\% of magnesium $(\mathrm{Mg})$ and $12.9 \%$ of sulfur $(\mathrm{S})$ (MagnaGrow; PQ Corp., Valley Forge, PA). Each plant received $10 \mathrm{~g}$ of $18 \mathrm{~N}-2.6 \mathrm{P}-6.6 \mathrm{~K}$ controlled-release fertilizers (Florikan; Florikan, Sarasota, FL) on 16 May and $150 \mathrm{~mL}$ $24 \mathrm{~N}-3.5 \mathrm{P}-13.2 \mathrm{~K}$ of micronutrient fertilizers (Miracle-Gro water-soluble all-purpose plant food; Scotts Co., Marysville, OH) on 19 May. Plants were hand watered daily as needed. The second experiment (Expt. 2) was conducted at a commercial nursery (McMinnville, TN) in a field plot with Waynesboro loam soil. 'Jane' magnolia plants were transplanted into the field with $6 \times 8$-ft row spacing in Apr. 2015. A vegetation-free strip $(3 \mathrm{ft}$ wide) was maintained within each row with herbicide applications as needed and rows were separated by a 6 -ft grass strip. Plants were top-

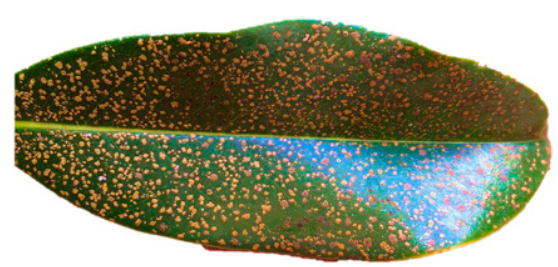

Fig. 1. Algal leaf spot caused by Cephaleuros virescens infecting magnolia.

dressed with $72 \mathrm{~g} 19 \mathrm{~N}-0.9 \mathrm{P}-6.1 \mathrm{~K}$ controlled-release fertilizer (Florikan) in Aug. 2015, Apr. and Aug. 2016, and Apr. and Aug. 2017. Plants did not receive supplemental irrigation in 2015,2016 , and 2017. No maintenance pesticides were applied in either experiment other than test fungicides. Eleven fungicides representing 10 active ingredients were evaluated as protective foliar applications for their ability to manage naturally occurring infection by algal leaf spot caused by $C$. virescens of magnolia following the IR-4 Environmental Horticulture Program protocol 17016 (IR-4 Project, 2017) (Table 1). The treatments were applied according to labeled rates provided by registrants. Each treatment had six single plant replications, which were arranged in a randomized complete block design. Plants were sprayed with treatments until runoff from the foliage using a backpack carbon dioxide $\left(\mathrm{CO}_{2}\right)$-pressurized sprayer with a tapered edge flat spray pattern stainless steel nozzle (TP8002VS; TeeJet Technologies, Springfield, IL) nozzle at 40 psi. The control group did not receive any treatments. All magnolia plants were naturally infected with algal leaf spot. Symptomatic leaves were collected from both experimental sites to identify the causative organism. Morphological characteristics under light microscope and colony characteristics on Bold's basal medium (Bischoff and Bold, 1963) were consistent with those for C. virescens (Thompson and Wujek, 1997). No other plant pathogens were identified using potato dextrose agar and water agar media.

The first experiment was conducted from 19 July 2017 to 23 Aug. 2017. The plants were evaluated for algal leaf spot disease severity, phytotoxicity, and defoliation on 18 and 26 July, and 2, 9, 16, and 23 Aug. 2017, and plant height and width were 
Table 1. List of chemical- and biological-based products and application dates according to IR-4 protocol for management of algal leaf spot, caused by Cephaleuros virescens, on container-grown southern magnolia and field-grown 'Jane' magnolia.

\begin{tabular}{|c|c|c|c|c|}
\hline Treatment $^{\mathrm{z}}$ & $\begin{array}{l}\text { Active ingredient } \\
\text { concn }(\%)\end{array}$ & $\begin{array}{l}\text { Application } \\
\text { dates }^{\mathrm{y}}\end{array}$ & Trade name & $\begin{array}{l}\text { Fungicide Resistance Action } \\
\text { Committee (FRAC) code }\end{array}$ \\
\hline Azoxystrobin + benzovindiflupyr & $30.0+15.0$ & $1,2,3$ & Mural & $11+7$ \\
\hline Bacillus amyloliquefaciens strain D747 & 98.85 & $1,2,3$ & Double Nickel LC & F6 \\
\hline Chlorothalonil water-dispersible granule & 82.5 & 1 & Daconil ULTREX & M 05 \\
\hline Copper octanoate & 10.0 & $1,2,3$ & Camelot O & M 01 \\
\hline Hydrogen peroxide + peroxyacetic acid & $27.1+2.0$ & $1,2,3$ & ZeroTol 2.0 & $\mathrm{NC}^{\mathrm{x}}$ \\
\hline $\begin{array}{l}\text { Mono- and di-potassium salts of phosphorus } \\
\text { acid + hydrogen peroxide }\end{array}$ & $27.1+14.0$ & $1,2,3$ & OxiPhos & P 07 \\
\hline Potassium bicarbonate & 85.0 & $1,2,3$ & MilStop & $\mathrm{NC}^{\mathrm{x}}$ \\
\hline Sodium carbonate peroxyhydrate & 85.0 & $1,2,3$ & GCPRO & $\mathrm{NC}^{\mathrm{x}}$ \\
\hline
\end{tabular}

${ }^{\mathrm{z}} 0.5 \mathrm{~mL} \cdot \mathrm{L}^{-1}$ azoxystrobin + benzovindiflupyr (Syngenta, Greensboro, NC), $10 \mathrm{~mL} \cdot \mathrm{L}^{-1}$ Bacillus amyloliquefaciens strain D747 (Certis USA, Columbia, MD), $1.56 \mathrm{~mL} \cdot \mathrm{L}^{-1}$ chlorothalonil suspension concentrate (Syngenta), $1.44 \mathrm{~g} \cdot \mathrm{L}^{-1}$ chlorothalonil water-dispersible granule (Syngenta), $10 \mathrm{~mL} \cdot \mathrm{L}^{-1} \mathrm{copper}$ octanoate $($ SePRO, Carmel, IN), 1.20 $\mathrm{g} \cdot \mathrm{L}^{-1}$ copper oxychloride (Albaugh, Ankeny, IA), $1.95 \mathrm{~mL} \cdot \mathrm{L}^{-1}$ didecyl dimethyl ammonium chloride (Pace 49 , Delta, BC, Canada), $20 \mathrm{~mL} \cdot \mathrm{L}^{-1}$ hydrogen peroxide + peroxyacetic acid (BioSafe Systems, Hartford, CT), $20 \mathrm{~mL} \cdot \mathrm{L}^{-1}$ mono- and di-potassium salts of phosphorous acid + hydrogen peroxide (BioSafe Systems), 3 g. $\mathrm{L}^{-1}$ potassium bicarbonate (BioWorks, Victor, NY), $4.79 \mathrm{~g} \cdot \mathrm{L}^{-1}$ sodium carbonate peroxyhydrate (BioSafe Systems) $1 \mathrm{~mL} \cdot \mathrm{L}^{-1}=0.1280 \mathrm{fl} \mathrm{oz} / \mathrm{gal}, 1 \mathrm{~g} \cdot \mathrm{L}^{-1}=0.1335 \mathrm{oz} / \mathrm{gal}$.

${ }^{\mathrm{y}}$ Expt. $1: 1=19$ July $2017,2=26$ July $2017,3=2$ Aug. 2017; Expt. $2: 1=22$ Aug. 2017, $2=29$ Aug. $2017,3=5$ Sept. 2017.

${ }^{\mathrm{x}}$ Not classified.

measured on 19 July and 23 Aug. 2017. Plant marketability was evaluated on 23 Aug. 2017. The average maximum temperatures for 19 to 31 July and 1 to 23 Aug. were 33.0 and $30.6{ }^{\circ} \mathrm{C}$, respectively. Average minimum temperatures were 20.4 and $19.0{ }^{\circ} \mathrm{C}$, respectively. Total rainfall was 1.6 and 3.79 inches, respectively.

The second experiment was conducted from 22 Aug. 2017 to 19 Sept. 2017. The algal leaf spot disease severity, phytotoxicity, and defoliation evaluations were conducted on 22 and 29 Aug. and 5, 12, and 19 Sept. 2017. Plant height and width were measured on 22 Aug. and 19 Sept. 2017. Plant marketability was evaluated on 19 Sept. 2017. The average maximum temperatures for 22-31 Aug. and 1-19 Sept. were 28.3 and $25.4{ }^{\circ} \mathrm{C}$, respectively. Average minimum temperatures were 16.1 and $13.5{ }^{\circ} \mathrm{C}$, respectively. Total rainfall was 0.72 and 4.72 inches, respectively.

The observations on disease severity, marketability, phytotoxicity, and defoliation were made after application of treatment in a weekly interval for 5 weeks. Algal leaf spot disease severity was evaluated based on the percentage of foliage exhibiting symptoms using a scale of $0 \%$ to $100 \%$ foliage area affected. The disease progress [area under disease progress curve (AUDPC)] was calculated using the formula $\sum\left\{\left[\left(x_{i}+x_{i}-\right.\right.\right.$ 1) $\left./ 2]\left(t_{i}-t_{i}-1\right)\right\}$, where $x_{i}$ is algal leaf spot disease severity rating on each evaluation date and $\left(t_{i}-t_{i}-1\right)$ is the number of days between evaluations. The plant marketability was evaluated using a scale of 1 to 10 ( $1=$ perfect plant, densely supplied with healthy, vigorous leaves of normal size, shape, color and texture, disease damage barely perceptible; $6=$ commercially acceptable plant, well supplied with leaves of normal size, shape, color and texture, disease damage confined; $10=$ nonmarketable plant, fairly supplied with leaves of small size, shape, chlorosis, and abundant disease damage). Phytotoxicity data were evaluated using a scale of 0 to 10 ordinal scale $(0=$ no phytotoxicity, $10=$ complete kill). Defoliation was also evaluated using 0 to 10 ordinal scale $(0=$ no loss of leaves, $10=$ complete loss of leaves).

Disease severity, disease progress (AUDPC), plant height and width, plant quality/marketability, phytotoxicity, and defoliation were compared among the treatments for both experiments. One-way analysis of variance (ANOVA) was performed using general linear model (PROC GLM) to partition the variance between disease severity, AUDPC, plant height and width, plant quality/marketability, phytotoxicity, and defoliation into source attributable to treatments and errors using statistical software (SAS version 9.4 for Windows; SAS Institute, Cary, NC). Treatment means were separated using Tukey's Studentized range test $(\alpha=0.05)$. All data met the ANOVA assumptions of normality and constant variance except for disease severity, disease progress (AUDPC) of Expt. 1 and plant marketability of Expts. 1 and 2, where variances were unequal. The Box-Cox transformation method was chosen for the appropriate transformation of data; however, it did not alleviate the nonconstant variance. Instead, Welch's $t$ test was chosen to partition variance in disease severity, and disease progress for Expt. 1 into source attributable to treatment and errors assuming unequal variance (Welch, 1947; Zheng et al., 2012) and means were separated by least square means $(\alpha=0.05)$. Kruskal-Wallis $\chi^{2}$ test was used to partition the variance in plant marketability values (Expts. 1 and 2 ) into source attributable to treatment and errors (PROC NPARIWAY) $(\alpha=$ $0.05)$.

\section{Results}

EFFICACY OF CHEMICAL AND BIOLOGICAL-BASED PRODUCTS IN MANAGEMENT OF ALGAL LEAF SPOT ON SOUTHERN MAgNolia: ExPT. 1. Algal leaf spot infection occurred naturally, and disease pressure was low with severity reaching $3.7 \%$ in the nontreated southern magnolia plants. All of the treatments significantly reduced algal leaf spot disease severity $(\mathrm{F}=12.72, P<0.0001)$ and $\operatorname{AUDPC}(\mathrm{F}=24.35, P<0.0001)$ compared with the nontreated control (Table 2). The fungicides that most effectively reduced algal leaf 
spot disease severity were copper octanoate, copper oxychloride, chlorothalonil water-dispersible granules (WDG), chlorothalonil suspension concentrate (SC), didecyl dimethyl ammonium chloride, azoxystrobin + benzovindiflupyr, hydrogen peroxide + peroxyacetic acid, and mono- and di-potassium salts of phosphorus acid + hydrogen peroxide (Table 2). Plants treated with biorational products sodium carbonate peroxyhydrate, Bacillus amyloliquefaciens strain D747 and potassium bicarbonate had significantly higher disease severity than other treatments (Table 2). The foliar applications of copper octanoate, copper oxychloride, chlorothalonil WDG, chlorothalonil SC, didecyl dimethyl ammonium chloride, azoxystrobin + benzovindiflupyr, hydrogen peroxide + peroxyacetic acid, and mono- and di-potassium salts of phosphorus acid + hydrogen peroxide were more effective in reducing disease progress than the foliar applications of $B$. amyloliquefaciens strain D747 and potassium bicarbonate.

Initial plant heights and widths did not vary among treatments, which ranged from an average of 36.0 to $41.3 \mathrm{~cm}$ and 25.6 to $28.0 \mathrm{~cm}$, respectively (data not shown). After completion of treatments, the final plant heights and widths ranged from an average of 51.5 to $58.0 \mathrm{~cm}$ and 33.0 to $37.1 \mathrm{~cm}$, respectively (data not shown). Plants treated with azoxystrobin + benzovindiflupyr and potassium bicarbonate had significantly higher incremental growth in plant height compared with the nontreated control magnolia plants at the end of the experiment $[\mathrm{F}=3.27, P=0.0015$ (Table 3)]. However, there were no significant differences in incremental growth in plant width between treated and nontreated control magnolia plants $(\mathrm{F}=2.01, P=0.042)$.

The plant marketability was significantly better in all treated southern magnolia plants compared with the nontreated control plants at the end of the experiment $\left[\chi^{2}=45.95\right.$, $P<0.0001$ (Fig. 2)]. However, all plants including nontreated control plants were commercially acceptable (Fig. 2). Phytotoxicity and defoliation were not observed in any of the treated southern magnolia plants (data not shown).

EFFICACY OF CHEMICAL AND BIOLOGICAL-BASED PRODUCTS IN MANAGEMENT OF ALGAL LEAF SPOT ON 'Jane' MAgnolia: Expt. 2. Algal leaf spot infection occurred naturally, and disease pressure was moderate, with severity reaching $34.6 \%$ in the nontreated 'Jane' magnolia plants. All of the treatments significantly reduced algal leaf spot disease severity $(\mathrm{F}=137.13, P<0.0001)$ and disease progress $(\mathrm{F}=56.22, P<0.0001)$ compared with the nontreated control plants (Table 2). The fungicides that most effectively reduced algal leaf spot disease severity were azoxystrobin + benzovindiflupyr, copper oxychloride, and didecyl dimethyl ammonium chloride (Table 2). The foliar applications of azoxystrobin + benzovindiflupyr, didecyl dimethyl ammonium chloride, copper oxychloride, chlorothalonil WDG, and sodium carbonate peroxyhydrate were more effective in reducing disease progress the foliar applications of potassium bicarbonate, B. amyloliquefaciens strain D747, mono- and di-potassium salts of phosphorus acid + hydrogen peroxide, and hydrogen peroxide + peroxyacetic acid.

Initial plant heights and widths ranged from an average of 186 to 207 $\mathrm{cm}$ and 120 to $141 \mathrm{~cm}$, respectively (data not shown). After completion of treatments, the final heights and widths of magnolia plants measured from an average of 190 to $210 \mathrm{~cm}$ and 128 to $152 \mathrm{~cm}$, respectively (data not

Table 2. Efficacy of protective foliar application of different chemical- and biological-based products (Table 1 ) in managing algal leaf spot, caused by Cephaleuros virescens, disease severity and disease progress [area under disease progress curve (AUDPC)] in container-grown southern magnolia (Expt. 1) and field-grown 'Jane' magnolia (Expt. 2). The control treatment included the nontreated plants naturally infected with algal leaf spot.

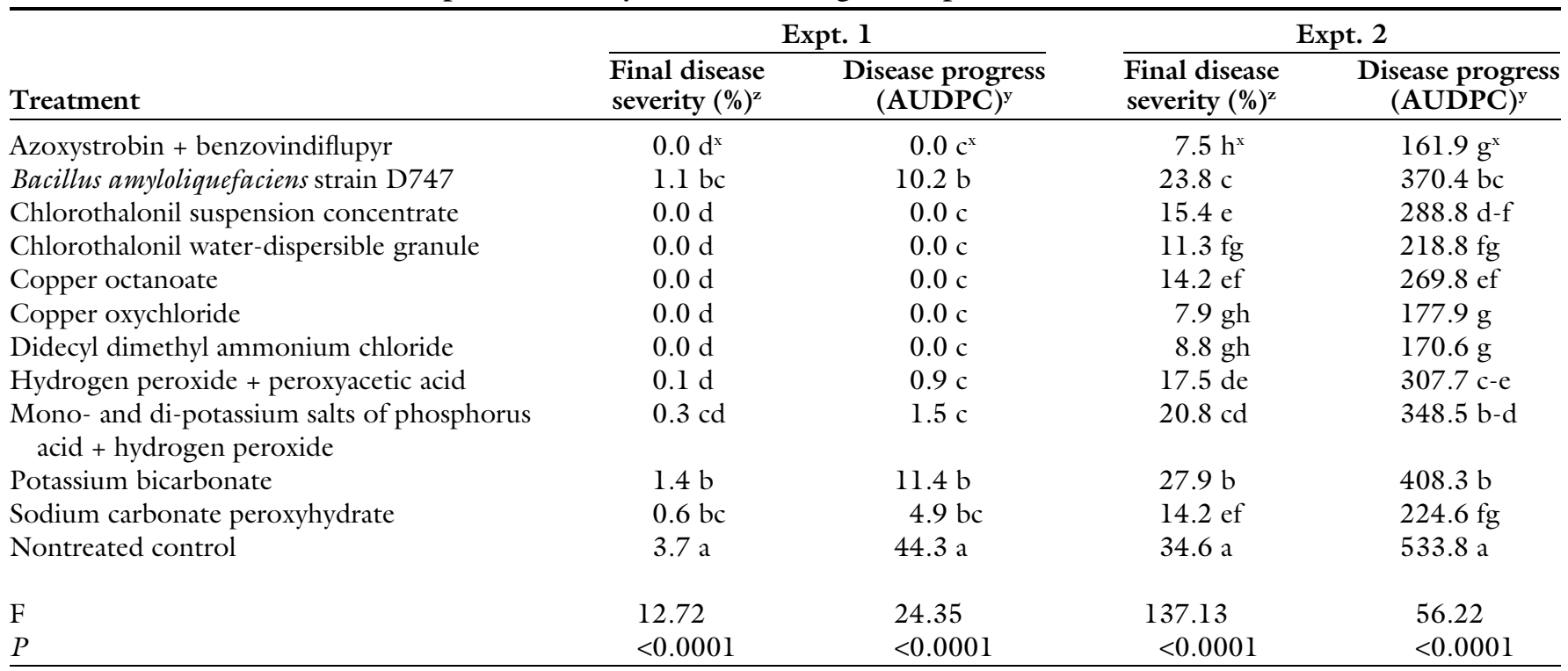

${ }^{\mathrm{z}}$ Final disease severity evaluated on 23 Aug. 2017 for Expt. 1 and 19 Sept. 2017 for Expt. 2. Values were the means of six single plant replications in each treatment.

${ }^{y}$ Disease progress (AUDPC) values were mean disease progression during the entire experimental period and calculated using the formula: $\sum\left\{\left[\left(x_{i}+x_{i}-1\right) / 2\right]\left(t_{i}-t_{i}-1\right)\right\}$, where $x_{i}$ is algal leaf spot disease severity on each evaluation date and $\left(t_{i}-t_{i}-1\right)$ is the number of days between evaluations. Values were the means of six single plant replications that were evaluated from 19 July 2017 to 23 Aug. 2017 (Expt. 1) and 22 Aug. 2017 to 19 Sept. 2017 (Expt. 2).

${ }^{\mathrm{x}}$ Treatment means within columns followed by different letters were significantly different $(P \leq 0.05)$. One-way analysis of variance was used to partition variance in disease severity and AUDPC. Treatment means were separated using Tukey's Studentized range test $(\alpha=0.05)$. 
Table 3. Incremental growth of southern magnolia (Expt. 1) and 'Jane' magnolia (Expt. 2) plants treated with biologicaland chemical-based products (Table 1) for managing algal leaf spot, caused by Cephaleuros vivescens, disease severity and disease progress [area under disease progress curve (AUDPC)]. The control treatment included the nontreated plants naturally infected with algal leaf spot. Values are the means of six single plant replications in each treatment.

\begin{tabular}{|c|c|c|c|c|}
\hline \multirow[b]{2}{*}{ Treatment } & \multicolumn{2}{|c|}{ Expt. 1} & \multicolumn{2}{|c|}{ Expt. 2} \\
\hline & $\begin{array}{l}\text { Increase in plant } \\
\text { width }(\mathrm{cm})^{\mathrm{z}}\end{array}$ & $\begin{array}{c}\text { Increase in } \\
\text { plant ht }(\mathrm{cm})\end{array}$ & $\begin{array}{l}\text { Increase in plant } \\
\text { width }(\mathrm{cm})\end{array}$ & $\begin{array}{c}\text { Increase in } \\
\text { plant ht }(\mathrm{cm})\end{array}$ \\
\hline Azoxystrobin + benzovindiflupyr & $8.17 \pm 0.25 \mathrm{a}^{\mathrm{y}}$ & $20.67 \pm 0.80 \mathrm{a}^{\mathrm{y}}$ & $7.08 \pm 1.50 \mathrm{a}^{\mathrm{y}}$ & $2.50 \pm 1.71 \mathrm{a}^{\mathrm{y}}$ \\
\hline Bacillus amyloliquefaciens strain D747 & $8.20 \pm 0.96 a$ & $17.83 \pm 0.79 \mathrm{a}-\mathrm{c}$ & $7.92 \pm 3.44 \mathrm{a}$ & $2.50 \pm 1.12 \mathrm{a}$ \\
\hline Chlorothalonil suspension concentrate & $9.00 \pm 0.70 \mathrm{a}$ & $16.00 \pm 2.37 \mathrm{a}-\mathrm{c}$ & $8.33 \pm 2.20 \mathrm{a}$ & $3.33 \pm 1.05 \mathrm{a}$ \\
\hline Chlorothalonil water-dispersible granule & $8.42 \pm 0.55 \mathrm{a}$ & $16.00 \pm 0.68 \mathrm{a}-\mathrm{c}$ & $10.83 \pm 3.07 \mathrm{a}$ & $3.33 \pm 1.67 \mathrm{a}$ \\
\hline Didecyl dimethyl ammonium chloride & $7.50 \pm 0.26 \mathrm{a}$ & $19.17 \pm 1.08 \mathrm{a}-\mathrm{c}$ & $10.00 \pm 1.58 \mathrm{a}$ & $3.33 \pm 1.67 \mathrm{a}$ \\
\hline Hydrogen peroxide + peroxyacetic acid & $7.42 \pm 0.44 \mathrm{a}$ & $18.50 \pm 1.31 \mathrm{a}-\mathrm{c}$ & $11.67 \pm 2.55 \mathrm{a}$ & $4.17 \pm 1.54 \mathrm{a}$ \\
\hline $\begin{array}{l}\text { Mono- and di-potassium salts of phosphorus } \\
\text { acid }+ \text { hydrogen peroxide }\end{array}$ & $9.58 \pm 0.92 \mathrm{a}$ & $17.00 \pm 0.73 \mathrm{a}-\mathrm{c}$ & $11.25 \pm 4.69 \mathrm{a}$ & $4.17 \pm 1.54 \mathrm{a}$ \\
\hline Potassium bicarbonate & $8.42 \pm 0.47 \mathrm{a}$ & $20.00 \pm 1.37 \mathrm{ab}$ & $9.58 \pm 3.12 \mathrm{a}$ & $4.17 \pm 1.54 \mathrm{a}$ \\
\hline Sodium carbonate peroxyhydrate & $8.67 \pm 0.53 \mathrm{a}$ & $18.83 \pm 1.22 \mathrm{a}-\mathrm{c}$ & $6.25 \pm 1.07 \mathrm{a}$ & $3.33 \pm 1.67 \mathrm{a}$ \\
\hline$P$ & 0.04 & 0.001 & 0.92 & 0.99 \\
\hline
\end{tabular}

${ }^{\mathrm{z}} 1 \mathrm{~cm}=0.3937$ inch.

${ }^{\mathrm{y}}$ Treatment means within columns followed by different letters were significantly different $(P \leq 0.05)$. One-way analysis of variance was used to partition variance in plant height and width. Treatment means were separated using Tukey's Studentized range test $(\alpha=0.05)$.

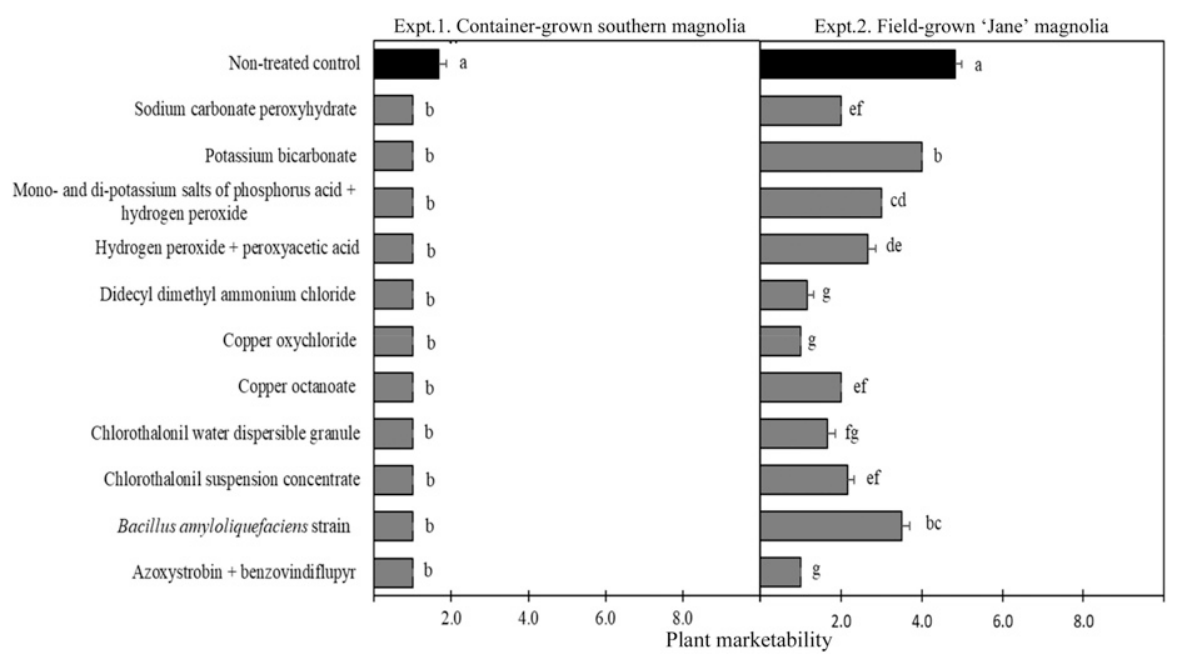

Fig. 2. Plant marketability results of magnolia plants after foliar application of different chemical and biological-based products (Table 1) for naturally occurring algal leaf spot, caused by Cephaleuros virescens. Foliar applications of treatments were made until runoff using the backpack carbon dioxide-pressurized tank attached to a tapered edge flat spray pattern stainless steel nozzle. The plant marketability was evaluated using a scale of 1 to $10(1=$ perfect plant, densely supplied with healthy, vigorous leaves of normal size, shape, color and texture, disease damage barely perceptible; $6=$ commercially acceptable plant, well supplied with leaves of normal size, shape, color and texture, disease damage confined; 10 = nonmarketable plant, fairly supplied with leaves of small size, shape, chlorosis, and abundant disease damage) on 23 Aug. 2017 (Expt. 1: container-grown southern magnolia) and 29 Sept. 2017 (Expt. 2: field-grown 'Jane' magnolia). Values were the means of six single plant replications for each treatment. The control treatment included the nontreated naturally infected plants with algal leaf spot (nontreated control). Letters beside the bars represent significant differences in plant marketability of magnolia plants between the treatments compared with the nontreated controls (Expt. $1: \chi^{2}=45.95, P<$ 0.0001 ; Expt. 2 : $\left.\chi^{2}=65.99, P<0.0001\right)$. shown). There were no significant differences in terms of incremental growth in plant height and width among treated and nontreated control magnolia plants [plant height increment: $\mathrm{F}=0.19, P=0.99$; plant width increment: $\mathrm{F}=1.25, P=0.28$ (Table 3)].

The plant marketability was significantly better in all treated plants compared with the nontreated control plants at the end of the experiment $\left[\chi^{2}=65.99, P<0.0001\right.$ (Fig. 2)]. Plants treated with azoxystrobin + benzovindiflupyr, copper oxychloride, and didecyl dimethyl ammonium chloride maintained the best plant marketability. However, all plants including nontreated control plants were commercially acceptable (Fig. 2). Phytotoxicity and defoliation were not observed in any of the treated 'Jane' magnolia plants (data not shown).

\section{Discussion}

Algal leaf spot is a threat during nursery crop production, as it can cause primary (direct) and also lead to secondary (indirect) infection or disease (Browne et al., 2019). With primary infection, reduced transpiration, photosynthetic rate, and stomatal conductance were observed in infected tea plants (Ramya and Ponmurugan, 2012), whereas algal leaf 
spot can form associations with other pathogens resulting in severe symptoms. In addition, decreased leaf pigments, nitrogen and amino acids, sugar, and other essential biochemical constituents were reported in infected plants.

In this study, different biological- and chemical-based fungicides were evaluated for their ability to manage algal leaf spot caused by $C$. virescens in two different nursery production settings using container-grown southern magnolia and field-grown 'Jane' magnolia plants. Algal leaf spot disease severity and disease progress were high in the field-grown 'Jane' magnolia trial (Expt. 2) compared with the container-grown southern magnolia trial (Expt. 1), likely due to variability in magnolia species, crop growth stage, crop maintenance, and site conditions, including weather patterns. Browne et al. (2019) also observed variable algal leaf spot disease severity among locations and years due to variable weather conditions or crop management practices.

B. amyloliquefaciens is a grampositive bacterium used commercially as biofertilizer and biocontrol agent to control different phytopathogens (Chowdhury et al., 2015). B. amyloliquefaciens strain D747 (Double Nickel LC; Certis USA, Columbia, MD) showed good efficacy in reducing algal leaf spot disease severity in magnolia plants. The antagonistic activity of the biocontrol agent is due to competition for nutrients and niches as well as production of antimicrobial metabolites, and mycoparasitism (Chowdhury et al., 2015; Liu et al., 2013; Lopes et al., 2015).

Copper-based products have been used for the management of algal disease in economically important crops such as tea (Huq and Ali, 2010). Copper fungicides are classified as multisite and inhibit pathogen growth by disrupting the cellular protein (Chase, 2010). In this study, copper oxychloride (COC DF; Albaugh, Ankeny, IA) effectively controlled algal leaf spot disease severity and disease progress in both experiments. This finding was similar to that of Coates et al. (2009), where copper oxychloride was effective in managing algal leaf spot on mango. According to Kumar et al. (2017), spraying of
$0.3 \%$ of copper oxychloride was recommended for effective management of C. virescens on litchi (Litchi chinensis). Copper octanoate (Camelot O; SePRO, Carmel, IN) also substantially reduced the disease severity and disease progress in the current study. Both copper fungicides, copper oxychloride and copper octanoate, had statistically similar levels of disease suppression in Expt. 1; however, efficacy of copper oxychloride was statistically superior to copper octanoate in Expt. 2.

Mono- and di-potassium salts of phosphorous acid + hydrogen peroxide (OxiPhos; BioSafe Systems, Harford, CT) substantially lowered the disease severity and disease progress compared with the nontreated control in this study. A similar result was observed by Browne et al. (2019), where potassium phosphite (mono- and di-potassium salts of phosphorous acid) significantly controlled algal orange cane blotch in blackberry caused by $C$. virescens. Potassium phosphite acts directly by inhibiting spore germination and growth (Dobrowolski et al., 2008) or activating the plant's natural defense mechanism against different phytopathogens (Mucharromah and Kuc, 1991). In addition, hydrogen peroxide causes oxidative damage of cells and eventually death of the target pathogen (National Center for Biotechnology Information, 2020).

Potassium bicarbonate (MilStop; BioWorks, Victor, NY) showed low to moderate performance in reducing the algal leaf spot disease severity and disease progress in both experiments compared with the nontreated control. Potassium bicarbonate is a nonsystemic fungicide and its efficacy depends on the contact; it causes the collapse of the hyphal wall and shrinkage of conidia of the pathogen, reducing the sporulation, growth and germination (Sawant and Sawant, 2008). Similarly, Palmer et al. (1997) observed that the anion of bicarbonate primarily decreased the colony growth of Botrytis cinerea spores in an in vitro study. Other mechanisms include the change in leaf surface $\mathrm{pH}$, and potassium imbalances.

Sodium carbonate peroxyhydrate is a granular algaecide used to treat filamentous algae and cyanobacteria (Geer et al., 2016). In this study, sodium carbonate peroxyhydrate (GCPRO;
BioSafe Systems ) effectively reduced the algal leaf disease severity and disease progression in comparison with nontreated controls. The antialgal activity of sodium carbonate peroxyhydrate could be due to production of reactive oxygen species such as hydrogen peroxide $\left(\mathrm{H}_{2} \mathrm{O}_{2}\right)$. When sodium carbonate peroxyhydrate comes in contact with moisture, it is transformed into hydrogen peroxide and sodium carbonate, which also have antifungal properties (Palmer et al., 1997). Hydrogen peroxide causes oxidative damage to mitochondrial cells and other critical components of target organisms and ultimately kills them (National Center for Biotechnology Information, 2020).

Two sanitizers known for antimicrobial properties were screened: didecyl dimethyl ammonium chloride (KleenGrow; Pace 49, Delta, BC, Canada) and hydrogen peroxide + peroxyacetic acid (ZeroTol 2.0, BioSafe Systems). Didecyl dimethyl ammonium chloride and hydrogen peroxide + peroxyacetic acid showed good efficacy in managing algal leaf spot disease severity and disease progress in magnolia plants. A similar result was observed by BaysalGurel et al. (2014), where didecyl dimethyl ammonium chloride substantially reduced the $B$. cinerea incidence in tomato (Solanum lycopersicum) fruit. These two treatments cause the membrane disruption of a target pathogen and inhibit pathogen growth and development (Gilbert and Moore, 2005; Newman, 2004), thus providing broad-spectrum control against algal leaf spot disease. The efficacy of both products was statistically similar in Expt. 1, whereas didecyl dimethyl ammonium chloride was more effective than hydrogen peroxide + peroxyacetic acid in Expt. 2 when disease pressure increased.

Chlorothalonil WDG (Daconil ULTREX; Syngenta, Greensboro, NC) and chlorothalonil SC (Daconil WeatherStik; Syngenta) significantly reduced algal leaf spot disease severity and disease progression in this study. No differences in leaf spot disease severity and disease progression were observed between these two treatments in Expt. 1, whereas chlorothalonil WDG reduced disease severity and disease progression compared 
with chlorothalonil SC in Expt. 2. Performance differences could be related to formulation, leaf area index, the spray volume and percentage surface area covered by products applied, differential disease pressure, location, and weather conditions. On contact with a pathogen, chlorothalonil reacts in cells by replacing chlorine with sulfhydryl groups of glutathione and other low-molecular weight thiols, thus inhibiting activity of thiol-dependent enzymes (Barak and Edgington, 1984; Tillman et al., 1973). Efficacy of chlorothalonil has not been documented before in management of algal leaf spot of magnolia. Because chlorothalonil is a multisite contact fungicide, it has been used as a rotational and tank mix partner to avoid resistance development in crop diseases (Brenneman and Culbreath, 2000), and it is anticipated to act similarly for algal leaf spot.

The fungicide azoxystrobin + benzovindiflupyr (Mural; Syngenta) effectively controlled algal leaf spot severity and disease progress in both experiments. The benzovindiflupyr belongs to the succinate dehydrogenase inhibitor group and azoxystrobin belongs to the quinone outside inhibitor group of fungicide (Fungicide Resistance Action Committee, 2020). Both fungicides interfere with the cellular respiration process by blocking the mitochondrial electron transport system. This results in inhibition of the cellular energy cycle, and ultimately the pathogen dies (Veloukas and Karaoglanidis, 2012; Zeng et al., 2015). The combination of azoxystrobin + benzovindiflupyr may have added flexibility (multiple target sites) in their action against algal leaf spot, providing better algal leaf spot disease management compared with other treatments.

Plant growth parameters such as height and width were not influenced by the application of treatments in this study. However, treated plants had better quality compared with the nontreated southern magnolia and 'Jane' magnolia plants. The superior quality of treated plants could be related to reduced symptom expression even though photosynthetic potential was not sufficiently improved to stimulate significant increases in plant growth.

The goal of this study was to help growers obtain better management of algal leaf spot disease on magnolia trees. Azoxystrobin + benzovindiflupyr, didecyl dimethyl ammonium chloride, and copper oxychloride performed best in both experiments whereas copper octanoate, chlorothalonil WDG, chlorothalonil SC, hydrogen peroxide + peroxyacetic acid, and mono- and di-potassium salts of phosphorous acid + hydrogen peroxide performed well with the light inoculum load. Depending on the disease pressure and necessity, the fungicides and biorational products should be rotated for effective disease suppression and to avoid any resistance development (Bika et al., 2020). For example, mono- and dipotassium salts of phosphorous acid + hydrogen peroxide can be effective if routinely sprayed in rotation among other similar tools, but azoxystrobin + benzovindiflupyr and copper oxychloride should be reserved for higher disease pressure and used in rotation to guard against the development of resistance to active ingredients. The efficacy of fungicides and biorational products hinges on different factors related to plants and application of products. This current study used two cultivars of magnolia plants. Disease severity, disease progress, and efficacy of products to maintain the marketability should be evaluated in different cultivars of southern magnolia to get a more complete knowledge of algal leaf spot management. In addition, knowledge on timing of application, concentrations, and combining or rotation of fungicides should be developed in future; the current study does not address these. A comprehensive study on the effect of weather factors, such as relative humidity and temperature, in disease development and progression should be carried out to allow better management of algal leaf spot disease.

Under the current circumstances, where there is not much information about algal leaf disease management on magnolia, growers should adopt an integrated disease management strategy. A good strategy would be incorporation of fungicides and biorational products with existing sanitary and cultural practices and rotating single site fungicides with multisite fungicides or biorational products, which will help to maintain the effectiveness and lifespan of available chemistries.

\section{Literature cited}

Barak, E. and L.V. Edgington. 1984. Cross-resistance of Botrytis cinerea to captan, thiram, chlorothalonil, and related fungicides. Can. J. Plant Pathol. 6:318-320, doi: 10.1080/07060668409501536.

Baysal-Gurel, F., S.A. Miller, and M. Bledsoe. 2014. Postharvest applications of disinfectants using a fog tunnel system to manage botrytis gray mold in tomatoes. Acta Hort. 1053:237-244, doi: 10.17660/ActaHortic.2014.1053.26.

Bika, R., F. Baysal-Gurel, and C. Jennings. 2020. Botrytis cinerea management in ornamental production: A continuous battle. Can. J. Plant Pathol., doi: 10.1080/ 07060661.2020.1807409.

Bischoff, H.W. and H.C. Bold. 1963. Some algae from enchanted rock and related algal species. Phycological studies IV. Univ. Texas Publ. No. 6318. Univ. of Texas, Austin, TX.

Brenneman, T.B. and A.K. Culbreath. 2000. Peanut disease control, p. 96-97. In: 2000 Georgia pest control handbook. Univ. Georgia Coop. Ext. Serv. Special Bul. No. 28.

Browne, F.B., P.M. Brannen, H. Scherm, J.R. Taylor, J.S. Shealey, L.A. Fall, and E.D. Beasley. 2019. Evaluation of disinfectants, algicides, and fungicides for control of orange cane blotch of blackberry in the field. Crop Prot. 122:112-117, doi: 10.1016/j.cropro.2019.04.019.

Chase, A.R. 2010. Mode of action of Ml: Copper. 6 June 2020. <https://www. greenhousemag.com/article/gmpro0210-copper-fungicides $>$.

Chowdhury, S.P., A. Hartmann, X.W. Gao, and R. Borriss. 2015. Biocontrol mechanism by root-associated Bacillus amyloliquefaciens FZB42 - A review. Front. Microbiol. 6:1-11, doi: 10.3389/fmicb.2015.00780.

Coates, L., C. Akem, T. Cooke, E. Dann, and A. Young. 2009. Mango, p. 157-173. In: T. Cooke, D.M. Persley, and S. House (eds.). Diseases of fruit crops in Australia. CSIRO Publ., Collingwood, VIC, Australia.

Dobrowolski, M.P., B.L. Shearer, I.J. Colquhoun, P.A. O'Brien, and G.E. Hardy. 2008. Selection for decreased sensitivity to phosphite in Phytophthora cinnamomi with prolonged use of fungicide. Plant Pathol. 57:928-936.

Fungicide Resistance Action Committee. 2020. FRAC code list 2020: Fungicides sorted by mode of action (including FRAC code numbering). 7 June 2020. <https:// www.frac.info/docs/default-source/ publications/frac-code-list/frac-code-list-2020 final5d632b2c512362eb9aleff00004acf5d. pdf?sfvrsn $=$ 9 940499a_2>. 
Geer, T.D., C.M. Kinley, K.J. Iwinski, A.J. Calomeni, and J.H. Rodgers. 2016. Comparative toxicity of sodium carbonate peroxyhydrate to freshwater organisms. Ecotoxicol. Environ. Saf. 132:202-211, doi: 10.1016/j.ecoenv.2016.05.037.

Gilbert, P. and L.E. Moore. 2005. Cationic antiseptics: Diversity of action under a common epithet. J. Appl. Microbiol. 99:703-715, doi: 10.1111/j.1365-2672. 2005.02664.x

Holcomb, G.E. 1986. Hosts of the parasitic alga Cephaleuros virescens in Louisiana and new host records for the continental United States. Plant Dis. 70:1080, doi: 10.1094/pd-70-1080.

Huq, M. and M. Ali. 2010. Efficacy or muriate of potash and foliar spray with fungicides to control red rust disease (Cephaleurous parasiticus) of tea. Bangladesh J. Agr. Res. 35:273-277, doi: 10.3329/ bjar.v35i2.5890.

IR-4 Project. 2017. Management tools for algal leaf spot. Protocol 17-016. 6 June 2020. <https://www.ir4project.org/ehc/ ehc-registration- support-research/envhort-researcher-resources/\#Protocols>.

Joubert, J.J. and F.H.J. Rijkenberg. 1971. Parasitic green algae. Annu. Rev. Phytopathol. 9:45-64, doi: 10.1146/annurev. py.09.090171.000401.

Knox, G., W. Klingerman, M. Paret, and A. Fulcher. 2012. Magnolia - Magnolia spp. 7 June 2020. <https://plantpath. ifas.ufl.edu/u-scout/ewExternalFiles/ ipm_trees_chapter_2012.pdf>.

Kumar, M., V. Kumar, N. Bhalla-Sarin, and A. Varma. 2017. Lychee disease management. Springer, Singapore. doi: 10.1007/978-981-10-4247-8.

Liu, P., L. Luo, and C. Long. 2013. Characterization of competition for nutrients in the biocontrol of Penicillium italicum by Kloeckera apiculata. Biol. Control 67:157-162, doi: 10.1016/ J.BIOCONTROL.2013.07.011.

Lopes, M.R., M.N. Klein, L.P. Ferraz, A.C. da Silva, and K.C. Kupper. 2015. Saccharomyces cerevisiae: A novel and efficient biological control agent for Colletotrichum acutatum during pre-harvest. Microbiol. Res. 175:93-99, doi: 10.1016/ J.MICRES.2015.04.003.

Mucharromah, E. and J. Kuc. 1991. Oxalate and phosphates induce systemic resistance against diseases caused by fungi, bacteria and viruses in cucumber. Crop Prot. 10:265-270, doi: 10.1016/02612194(91)90004-B.

National Center for Biotechnology Information. 2020. Pubchem compound summary for CID 159762, Sodium percarbonate. 7 June 2020. https:// pubchem.ncbi.nlm.nih.gov/compound/ Sodium-percarbonate.

Nelson, S.C. 2008. Cephaleuros species, the plant-parasitic green algae. Plant Dis. 43:1-6.

Newman, S.E. 2004. Disinfecting irrigation water for disease management. 24 Sept. 2020. <http://www.nurserycropscience. info/water/filtration-disinfection/otherreferences/newman-2004-disinfectingirrigation-water-paper.pdf $>$.

Old, K.M., L.S. See, and Z.Q. Yuan. 2000. A manual of diseases of tropical acacias in Australia, South-East Asia and India. Center for International Forestry Research.

Palmer, C. 2015. 2015 Biennial Priority Setting Workshop. 24 Sept. 2020. <https:/ www.ir4project.org/ehc/ehc-registrationsupport-research/env-hort-workshop/ 2015-biennial-priority-setting-workshop>.

Palmer, C.L., R.K. Horst, and R.W. Langhans. 1997. Use of bicarbonates to inhibit in vitro colony growth of Botrytis cinerea. Plant Dis. 81:1432-1438, doi: 10.1094/PDIS.1997.81.12.1432.

Pitaloka, M., V. Petcharat, S. Arikit, and A. Sunpapao. 2015. Cephaleuros virescens, the cause of an algal leaf spot on Para rubber in Thailand. Australas. Plant Dis. Notes 10:1-4.

Ramya, M. and P. Ponmurugan. 2012. Host-pathogen interaction studies between susceptible and tolerant tea clones in relation to red rust disease. Intl. J. Algae 14:380-389.

Rindi, F. and J. Lopez-Bautista. 2008. Diversity and ecology of Trentepohliales (Ulvophyceae, Chlorophyta) in French Guiana. Cryptogam., Algol. 29:13-43.

Ruehle, G.D. 1936. An epiphytic of algal spot in south Florida. Plant Dis. Rep. 20:221-222.

Sawant, S.D. and I.S. Sawant. 2008. Use of potassium bi-carbonates for the control of powdery mildew in table grapes. Acta Hort. 785:285-292, doi: 10.17660/ ActaHortic.2008.785.34.

Stevens, H.E. and R.B. Piper. 1941. Avocado disease in Florida. U.S. Dept. Agr. Circ. 582:1-47.

Suit, R.F. and E.P. DuCharme. 1946. The cephaleuros disease of citrus. Citrus Ind. 27:3.

Suit, R.F. 1949. Parasitic disease of citrus in Florida. Florida Agr. Exp. Sta. Bul. 463.

Sunpapao, A., M. Pitaloka, and S. Arikit. 2016. Short communication; algal leaf spot associated with Cephaleuros virescens (Trentepohiales, Ulvophyceae) on Nephelium lappaceium in Thailand. Biodiversitas 17:31-35.

Suto, Y. and S. Ohtani. 2009. Morphology and taxonomy of five Cephaleuros species (Trentepohliaceae, Chlorophyta) from Japan, including three new species. Phycologia 48:213-236.

Swingle, W.T. 1894. Cephaleuros mycoidea and Phylliosiphon, two species of parasitic algae new to North America. Proc. Amer. Assoc. Advan. Sci. 42:260.

Thompson, R.H. and D.E. Wujek. 1997. Trentepohliales: Cephaleuros, Phycopeltis, and Stomatochroon: Morphology, taxonomy, and ecology. Science Publ., Enfield, NH.

Tillman, R.W., M.R. Siegel, and J.W. Long. 1973. Mechanism of action and fate of the fungicide chlorothalonil (2,4,5,6-tetrachloroisophthalonitrile) in biological systems. I. Reactions with cells and subcellular components of Saccharomyces pastorianus. Pestic. Biochem. Physiol. 3:160-167, doi: 10.1016/0048-3575(73)90100-4.

Veloukas, T. and G.S. Karaoglanidis. 2012. Biological activity of the succinate dehydrogenase inhibitor fluopyram against Botrytis cinerea and fungal baseline sensitivity. Pest Manag. Sci. 68:858-864, doi: $10.1002 /$ ps.3241.

Welch, B. 1947. The generalization of student's problem when several different population variances are involved. Biometrika 34:23-35.

Wellman, F.L. 1972. Tropical American crops and their diseases. Scarecrow Press, Metuchen, NJ.

Wolf, F.A. 1830. A parasitic alga, Cephaleuros virescens Kunze, on citrus and certain other plants. J. Elisha Mitchell Sci. Soc. 45:187-205.

Zeng, F., E. Arnao, G. Zhang, G. Olaya, J. Wullschleger, H. Sierotzki, R. Ming, B.H. Bluhm, J.P. Bond, A.M. Fakhoury, and C.A. Bradley. 2015. Characterization of quinone outside inhibitor fungicide resistance in Cercospora sojina and development of diagnostic tools for its identification. Plant Dis. 99:544-550, doi: 10.1094/PDIS-05-14-0460-RE.

Zheng, L., J.M. Diamond, and D.L. Denton. 2012. Evaluation of whole effluent toxicity data characteristics and use of Welch's t-test in the test of significant toxicity analysis. Environ. Toxicol. Chem. 32:468-474, doi: 10.1002/etc.2075.

Zhu, H., H. Zhengyu, and G. Liu. 2017. Morphology and molecular phylogeny of Trentepohliales (Chlorophyta) from China. Eur. J. Phycol. 52:330-341. 